Марія ЧЕПІЛЬ, orcid.org/0000-0002-2215-3994 доктор педагогічних наук, професор, завідувач кафедри загальної педагогіки та дошкільної освіти Дрогобицького державного педагогічного університету імені Івана Франка (Дрогобич, Львівська область, Україна) chepilmaria@gmail.com

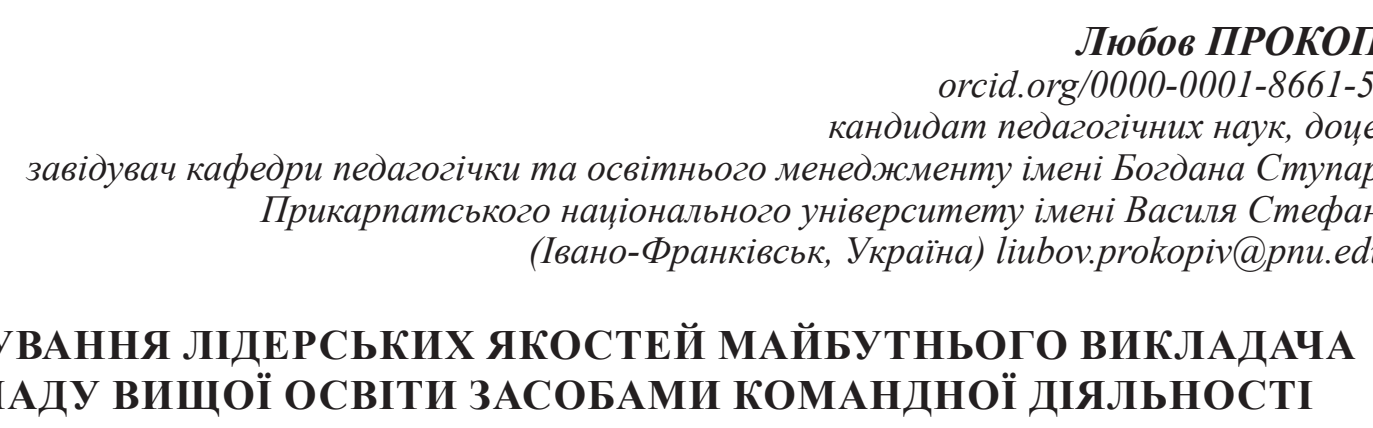

У роботі визначено сутність понять «лідер», «лідерство», та «лідерські якості», виділено провідні для викладачів ЗВО. З'ясовано, щчо формування лідерських якостей майбутніх викладачів є ефективним у командній діяльності. Дослідження сформувало основні засади педагогіки лідерства, надаючи пропозиції щзодо підтримки лідерських якостей.

Автори взяли участь в оціниі сформованості лідерських якостей через онлайн-технології, тестові методики, тощьо. На основі отриманих даних розроблено тести, анкетування, вправи та завдання для роботи у командній діяльності. Використано різноманітні технологї формування лідерських якостей: тренінги, онлайн-заняття, вебінари, індивідуальну роботу тощо. Вони показують результативність роботи авторів публікації.

У роботі подано експериментальний проект «Основи лідерства у командній діяльності», перевірено його ефективність. Проаналізовано педагогічні умови формування лідерських якостей: розвиток у студентів стійкої мотивації до формування лідерських якостей, урахування особливостей формування лідерських якостей у командній діяльності, стимулювання рефлексивного ставлення лідерів, здійснення моніторингу рівня сформованості у студентів лідерських якостей.

Оичнку сформованості лідерських якостей проводили незалежні експерти через використання Swat-аналізу, тестових методик. Зокрема, під час командного планування відеомосту «Яким має бути успішний лідер: бачення сторін» авторами проаналізовано особливості підготовки студентів спеціальності ОПН до проведення такої діяльності.

Вивчення питання формування лідерських якостей є необхідним, бо потребує не лише пошуку лідерів, а й нових підходів до їх регуляиї. Важсливим у формуванні лідерських якостей виступають компетентнісний, комунікативний, діяльнісний, мотиваційний підходи, щуо дає змогу майбутнім лідерам ефективно взаємодіяти.

Ключові слова: лідер, лідерські якості, формування, командна діяльність, майбутній викладач, Swat-аналіз.

Maria CHEPIL, orcid.org/0000-0002-2215-3994 Doctor of Pedagogical Sciences, Professor, Head of the Department of General Pedagogy and Preschool Education Drohobych Ivan Franko State Pedagogical University (Drohobych, Lviv region, Ukraine) chepilmaria@gmail.com

\author{
Liubov PROKOPIV, \\ orcid.org/0000-0001-8661-510X \\ Candidate of Pedagogical Sciences, Associate Professor, \\ Head of Bohdan Stuparyk Department of Pedagogy and Educational Management \\ Vasyl Stefanyk Precarpathian National University \\ (Ivano-Frankivsk, Ukraine) Liubov.prokopiv@pnu.edu.ua
}

\title{
DEVELOPMENT OF LEADERSHIP QUALITIES OF THE FUTURE TEACHER OF HIGHER EDUCATION INSTITUTIONS USING TEAMWORK
}

The paper defines the concepts "leader", "leadership", and "leadership qualities" and highlights the leading ones for teachers of higher education institutions (HEI). It was found that the development of leadership qualities of future 
teachers is effective when using teamwork. This study formed the basic principles of leadership pedagogy, providing suggestions for supporting leadership qualities.

The authors took part in assessing the formation of leadership qualities through online technologies, test methods, etc. Based on the obtained data, they developed tests, questionnaires, exercises, and tasks for teamwork. They used various technologies of leadership development, such as trainings, online classes, webinars, individual work, etc. They show the effectiveness of the work of authors of the publication.

The paper presents the developed experimental project Fundamentals of Leadership in Teamwork and proves its effectiveness. It contains analysis of the pedagogical conditions of development of leadership qualities: development of students' consistent motivation to form leadership qualities, consideration of peculiarities of development of leadership qualities in teamwork, stimulation of reflexive attitude of leaders, monitoring of students'leadership skills.

Assessment of the development of leadership qualities was carried out by independent experts using Swat-analysis, test methods. In particular, during the team planning of the video conference "What are characteristics of a successful leader: the vision of different parties", the authors analyzed the features of the preparation of students majoring in educational, pedagogical sciences for carrying out such activities.

The research of the development of leadership qualities is necessary because it requires not only the search for leaders, but also new approaches to their regulation. Competence-based, communicative, activity, motivational approaches are important in the development of leadership qualities and allow future leaders to interact effectively.

Key words: leader, leadership qualities, development, teamwork, future teacher, Swat-analysis.

Постановка проблеми. Сучасний стан розвитку соціуму за умов пандемії та онлайн-навчання вимагають зміни пріоритетів і перетворень в освітньому середовищі. Світ ще більше потребує пошуку лідерів, здатних створювати й управляти системами. Пошук лідерів і їх становлення варто починати з викладацького середовища, у якому створюється нова практика управління.

Сьогодні у питаннях формування лідерства виникають суперечності: між пошуком лідерів у суспільстві та відсутністю нових концептуальних основ їх підготовки; між вимогами суспільств до лідерів і невисоким рівнем готовності викладачів до їх формування; між потребою в оновленні змісту підготовки лідерів в освітньому процесі ЗВО та нерозробленістю освітніх програм для такого навчання.

Аналіз досліджень. Основні вимоги до рівня розвиненості лідерських якостей майбутніх викладачів ЗВО відображені у законодавчій базі України. (Закон України «Про вищу освіту», Стратегія розвитку сфери інноваційної діяльності на період до 2030 р.) (Стратегія, 2019). Проблема актуалізується у міжнародному контенті. Необхідність формування лідера виписана у «Hilti Outper forme» - програмі розвитку майбутніх лідерів-фахівців та ін. У всіх цих концептуальних положеннях наголошується на фаховій підготовці менеджерів освіти, здатних приймати швидкі та правильні рішення тощо.

Детально підходи до лідерства 3 погляду методології вивчено М. Діденко, В. Карманенко, С. Нестулею та ін. Аспекти лідерства 3 позиції педагогіки розкрито у працях А. Бойко, I. Зязюна, Н. Ничкало, А. Сбруєвої. Загальнотеоретичні основи лідерства розроблені Ф. Тейлор, А. Файолем та ін. Вчені наголошують на тому, що лідер володіє харизматичністю й особистісними рисами.

А. Адлер розкрив феномен лідерства через реалізацію людиною прагнення до зверхності, втілення нею на практиці думки «про свою богоподібність», переживаннями неусвідомленого комплексу власної неповноцінності, який вона відчувала у дитинстві (Адлер, 2015: 14). Сказане вище дає підстави стверджувати, що формування лідерських якостей розвивалися в рамках теорій менеджменту й освіти.

Мета статті - вивчення й узагальнення особливостей формування лідерських якостей майбутнього викладача з огляду на сучасні соціокультурні детермінанти.

Виклад основного матеріалу. Для системності та цілісності розгляду проаналізуємо основну термінологію дослідження. 3 огляду на тематику нашої публікації керуємося такими дефініціями, як:

Лідер - особистість, котра має на меті цілеспрямованість, контроль, зміну діяльності інших під час групової діяльності та здатна приймати рішення у важливих питаннях (Штогрин, Прокопів, 2020: 66). Таке тлумачення ми будемо використовувати у роботі.

Лідерство - здатність людини приймати необхідне та своєчасне рішення, не допускати втрат, «це один із механізмів інтеграції групової діяльності, коли індивід об'єднує та спрямовує дії на досягнення цілей» (Шатун, 2017: 73).

Лідерські якості відображають ставлення людини до інших людей і суспільства, виявляються в іiі суспільній поведінці та вчинках i, на нашу думку, пронизують усі компоненти зазначеної підготовки.

Європейський досвід формування лідерських якостей засобами командної діяльності передбачає 
запровадження нових підходів до лідерства (організацію онлайн-навчання, партнерство, роботу у громадських організаціях тощо); реалізацію практичних дій (різноманітні програми, створення умов для підготовки лідера тощо) (Werzejska, Karpenko, 2015).

Оскільки серед важливих якостей майбутнього викладача-лідера визначено інтелектуальні, моральні, організаторські й комунікативні, то проведене нами дослідження передбачало впровадження у практику роботи ЗВО умов формування лідерських якостей: мотивації, врахування специфіки роботи в команді під час онлайн-навчання, стимуляції рефлексивного ставлення студентів до лідерства, здійснення моніторингу тощо. Ці умови відображають основну ознаку формування лідерського середовища - командність. Лише завдяки командній роботі формування лідера буде якісним, суспільно активним.

Нами розроблені поетапні складники формування лідерських якостей майбутніх викладачів ЗВО засобами командної діяльності, які були апробовані у Прикарпатському національному університеті імені Василя Стефаника та Дрогобицькому державному педагогічному університеті імені Івана Франка.

На першому етапі ми надавали теоретичні аспекти із проблем лідерства, ступені володіння рольовими моделями лідерської поведінки.

Наведемо приклади питань, які виносяться на спільне обговорення:

1. Чи може кожний викладач стати лідером? Як стати лідером? На виховання яких особистісних якостей необхідно звернути особливу увагу викладачеві для формування лідерських якостей?

2. Як викладач має розвивати свої лідерські якості?

3. Як досягти професійного успіху?

4. Чи може лідер досягти успіху завдяки командній роботі?

5. Що таке дистрес? Як йому запобігти?

Результати такого обговорення показали, що теоретичні аспекти лідерства у майбутніх викладачів 3ВО не можна вважати достатніми для успішної роботи у команді. Незважаючи на зміни в організації підготовки майбутніх викладачів 3ВО, рівень їхніх лідерських якостей не відповідає теперішнім потребам. Задля сформованості таких якостей у майбутніх викладачів ЗВО було створено групу незалежних експертів, до якої увійшли викладачі університетів.

На другому етапі нами проаналізований досвід залучення студентів до командної роботи у двох університетах. Так, було з'ясовано, що в універ- ситетах діють молодіжні організації й органи студентського самоврядування: студентський парламент, студентський сенат, профспілка тощо. У Прикарпатському національному університеті імені Василя Стефаника студенти - майбутні лідери беруть участь у Проектно-освітньому центрі «Агенти змін».

Крім цього, на формування таких якостей у студентів впливає залучення їх до діяльності із громадськими організаціями на певних платформах, як от Платформи Громад, конкурси («Конкурс лідерів», «Вебінари лідерів», заняття з розвитку бізнес-ідей тощо); взаємодії 3 центрами зайнятості тощо.

3 урахуванням викладених вище ідей ми розбили процес формування лідерських якостей на окремі етапи, дотримання яких дозволило досягти запланованого результату. Зокрема, під час командного планування Відеомосту «Яким має бути успішний управлінець: бачення сторін» нами вивчено, проаналізовано і продемонстровано особливості підготовки студентів спеціальності ОПН до проведення такої діяльності. Нами запропоновано виховні впливи, які сприяли вдосконаленню зазначених якостей у студентів.

Після цього нами організовано загальне обговорення плану роботи, внесені певні зміни згідно iз пропозиціями та зауваженнями студентів. У процесі самої підготовки до роботи підвищувався рівень самостійності студентів як у плануванні роботи у команді, так і у прийнятті конкретних рішень щодо організації та проведення педагогічних заходів.

Зрозуміло, що для вдосконалення лідерських якостей важливо забезпечити реалізацію на гідному рівні усіх елементів командної роботи. Опишемо їх більш докладно.

1. Обговорення на онлайн-засіданнях порядку роботи і визначення відповідальних студентів. Допомога викладача.

2. Пропозиції щодо сценаріїв підготовки усім іншим студентам. Пошук у команді лідера.

3. Пропозиції лідера і сприйняття його ідей. Серед інших «масштабних» занять можна назвати конкурс ораторського мистецтва серед студентів спеціальності «Освітні, педагогічні науки» «Ти записався у лідери?», онлайн-журнал «Який він - лідер?» та ін. Важливо відзначити, що під час підготовки різних командних занять студентів налаштовували на те, щоб головна увага приділялася забезпеченню практичної корисності роботи в команді.

4. Проведення онлайн чи офлайн занять, під час яких відбувався аналіз шляхом серії завдань про лідерство кваліфікованої організації заняття. 
5. Спільне обговорення результатів роботи команди та лідера.

Одним із недоліків лідера у командній діяльності $€$ його невміння одночасно охопити своєю увагою всіх. Саме тому на етапі взаємодії зі студентами формування лідерських якостей вимагало взаємодопомоги.

На формування лідерських якостей у командній діяльності впливають інтерактивні технології, однак вони мають багато несподіванок, оскільки стиль інтеракції потребує швидкої зміни стилів спілкування і поведінки студентів. Часто майбутні лідери, залишаючись наодинці з аудиторією, втрачають можливості інтеракції, губляться.

Задля вдалого формування командної роботи 3 урахуванням викладених вище думок варті уваги колективні та індивідуальні консультації, обговорення типових труднощів в Інтернет-групах (Viber, Telegram) тощо. Майбутні лідери не повинні поспішати скаржитися на поведінку студентів. Студентам пропонувалося відкрито обговорити проблеми у взаєминах. Здебільшого колеги йшли на контакт і висловлювали свої думки щодо того, що їм не подобається у роботі майбутнього викладача.

Треба зауважити, що після такої роботи не тільки спостерігалося певне вдосконалення лідерських якостей, але і вироблялося самокритичне ставлення до себе.

На етапі формування мотивації ми проводили тренінги, інтерактивні методи навчання, які вимагали від молодих людей виявлення необхідних лідерських якостей у ситуаціях, максимально наближених до реальної практики.

Під час організації роботи з майбутніми викладачами нами враховувалися ідеї, сформульовані дослідниками американського Центру рефлексивного лідерства, Інституту публічних справ Хамфрі та Дорадчої Служби Університету Міннесоти [197]. Вони вважають, що одними з найбільш типових суспільних форм, де відбувається розподіл офіційної та неофіційної влади, $є$ форуми, арени та суди. Участь у них дозволяє людині виявити свої лідерські якості. Згідно з цією науковою позицією усі форми взаємодії людей, що за сутністю наближуються до вищеназваних, теж можна використовувати для ефективного вдосконалення лідерських якостей. Науковці пояснюють, що на форумах відбувається обговорення певних важливих проблем, які потребують сумісного розв'язання. Роль лідера в такій ситуації полягає в об'єднанні доповідачів та аудиторії для знаходження оптимальних рішень.

Провідною функцією лідера на форумі будьякого виду $\epsilon$ визначення переліку основних питань, організація ефективного обміну думок $\mathrm{i}$, як ідеальний варіант, знаходження оптимального рішення. Своєрідними прикладами форумів автори вважають робочі, дискусійні групи, публічні слухання, формальні дебати, телебачення та пресу, «мозкові атаки», ігри та ін.

Саме тому ми організовували онлайн«форуми», де від лідерів вимагалося чітко визначити мету, питання для обговорення, вимоги до виступів та ін. Таким чином вдавалося створити «ефект форуму», скористатися ним для вдосконалення лідерських якостей. Як різновид «обговорення» використовувалися конфліктні ситуації, які виникали стихійно або ж моделювалися як педагогічне завдання.

3 метою розвитку гнучкості, аналітичності, продуктивності, неординарності та інших інтелектуально-креативних якостей студентам пропонувалася значна кількість різнопланових завдань: iз залишком, недостачею та нечітко визначеними умовами, наявністю неоднозначно правильних варіантів вирішення тощо.

Важливо зауважити, що в реальній педагогічній практиці не $є$ рідкісними випадки, коли інтереси людей не узгоджуються між собою, а це приводить до конфліктної ситуації, проте кваліфікований викладач як лідер повинен вміти конструктивно підходити до будь-якого конфлікту.

Під час виконання вправ особлива увага студентів зверталася на чіткість мовлення. Відомо, що забезпечення чіткості та дохідливості пов'язані насамперед із пошуком людиною оптимального способу вираження у словесній формі своїх думок, щоб співрозмовникові було легко їх сприйняти та зрозуміти. Як результативні засоби назвемо: покращення словникового запасу, формування вмінь добирати мовленнєві конструкції, використовуючи певні методичні прийоми: аналіз текстів високохудожніх творів, своєчасну фіксацію незнайомих слів тощо.

Корисними для формування комунікативних якостей студентів були вправи на відпрацювання відомих засад мовлення: «узагальнення», «посилення» «наведення прикладу», спрямовані на підвищення уваги до підкреслення суб'єктивного характеру макроінформації.

Загалом удосконалення студентами власних лідерських якостей відбувалося у процесі їхньої реальної життєдіяльності й насамперед під час проходження педагогічної практики.

На наш погляд, формування зазначених якостей на цьому етапі має свої характерні особливості та виступає безперервним процесом, який продовжується протягом усього життя людини. 
Суттєвим компонентом нашої роботи було ознайомлення студентів із основами моделювання за допомогою моделювання якостей i навичок лідерства.

Основні етапи формування лідерських якостей не залежать від професійної специфіки: що саме роблять успішні керівники та «як» вони це роблять, складання опису ефективної поведінки керівника (інтерактивних засобів) і внутрішніх навичок (концептуальних засобів), які забезпечують успішну поведінку; навчання уміння переймати сутність кожного фрагменту «Як робити» щодо взаємин людей; аналіз структур, засобів, форм тощо (семінари, кількість груп та ін.), що дозволили успішно здійснювати реалізацію необхідних навичок (Дідух, 2018).

Важливим моментом згаданої роботи було те, що студенти не тільки знайомилися 3 корисними матеріалами із проблеми, але й засвоювали алгоритм, за яким можна результативно переймати в успішних лідерів їхні професійні таємниці.

Вважаємо, що для майбутніх викладачів-лідерів було корисним ознайомитися з рекомендаціями щодо створення позитивного іміджу; врахування інтересів інших людей; поступового зростання енергійності та життєстійкості у повсякденному житті, відкритості змінам та новому досвіду (Інноваційні педагогічні технології, 2015).

На нашу думку, важливим моментом формування лідерських якостей $є$ ефективний моніторинг. У процесі організації моніторингу сформованості ми враховували також такі аспекти, як: особлива увага до педагогічної діагностики; грунтування на сумісній діяльності та взаємодопомозі всіх учасників педагогічного процесу; проведення педагогічних діагностичних процедур, перед початком яких усі повинні бути морально та психологічно підготовлені до того, щоб сприймати результати спокійно, без хвилювань; виключення взаємовпливу під час проведення діагностичних процедур; проведення педагогічної діагностики та іiі результати в таємниці від інших.

На основі вищесказаного нами був розроблений експериментальний проєкт «Основи лідерства у командній діяльності». Метою проєкту стала потреба у формуванні лідерських якостей майбутніх викладачів, реалізації основних умов формування лідерських якостей. Під час проєкту ми поетапно застосовували зі студентами вищеописані умови.

Для перевірки виконаних умов нами проведено Swat-аналіз серед студентів спеціальностей «Освітні педагогічні науки» Дрогобицького державного педагогічного університету імені
Івана Франка та Прикарпатського національного університету імені Василя Стефаника (близько 60 респондентів).

У кожному із залучених ЗВО для досягнення цілей проєкту студенти працювали в онлайнсередовищі. Їм були подані інструктивні матеріали, основні досягнення у роботі. Місцем спілкування 3 учасниками проєкту стали вебінари й онлайн-зустрічі, форуми тощо. Формування лідерських якостей проходило під час планових (1/3 часу) і додаткових ( $2 / 3$ часу) зустрічей. Проєкт здійснювався завдяки підтримці ОТГ (зокрема Дзвиняцького ОТГ на Франківщині). Під час проєкту проводилися відео-тренінги та заняття онлайн-школи. Цікавим був підсумковий семінар «Лідерство і командоутворення у ЗВО». Інноваційні підходи та перспективи», на якому визначено подальші кроки у формуванні лідера.

Проведена робота щодо формування лідерський якостей майбутніх викладачів засобами командної діяльності у ЗВО показала, що співпраця будувалася на таких складниках, як: онлайн-навчання, комунікативна спрямованість, мотивація студента. Під час проєкту ми використовували технологію взаємодії кожного учасника команди, його рівноправне партнерство (техніку трикутника).

Суттєвим показником позитивних змін у розвиненості лідерських якостей майбутніх викладачів виступав також ступінь виявлення ними творчої активності. 3'ясувалося, що більшість студентів намагалися просто сумлінно виконувати розпорядження викладачів. Навпаки, переважна більшість студентів з експериментальних груп виявляли ініціативу у підготовці та проведенні проєкту. Вибір форми відбувався у них з урахуванням інтересів і бажань студентів, рівня їх вихованості та зумовлювався актуальними виховними завданнями.

Як результат сформованості лідерських якостей майбутніх викладачів ЗВО засобами командної діяльності, зросли впевненість, оптимізм, здатність до комунікації, покращилися лідерські позиції. Такі тенденції є достатньо позитивними. Результати проведеного SWAT-аналізу показали, що на сучасному етапі проблема формування лідера є вкрай необхідною (див. рис. 1).

Як видно з діаграми, у формуванні лідерських якостей засобами командної діяльності 75\% респондентів вбачають сильні сторони, лише 18\% слабкі. Щодо наслідків формування, то переважають позитивні зміни у формуванні лідерства.

Отже, проведене дослідження формування лідерських якостей майбутніх викладачів ЗВО засобами командної діяльності дозволило виявити позитивну динаміку. Водночас у сучасній 
науці та педагогічній практиці лише розпочалося впровадження формування лідерства у практиці освітньої діяльності, тому очікуємо подальшого розвитку цієї проблеми.

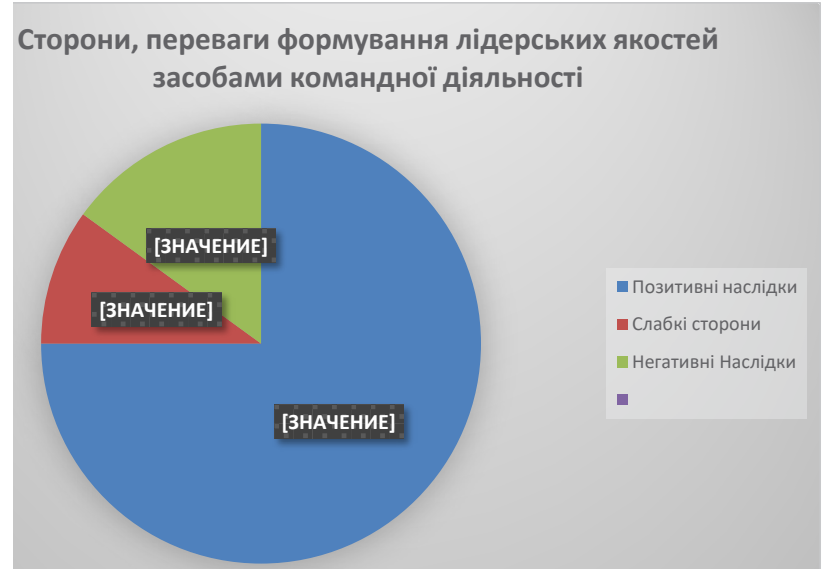

Рис. 1. Результати SWAT-аналізу

Висновки. Джерельна база дослідження дала можливість визначити та проаналізувати педаго- гічні умови ефективного формування лідерських якостей майбутніх викладачів у командній діяльності 3ВО: розвиток у студентів стійкої мотивації до формування лідерських якостей, урахування особливостей формування лідерських якостей у командній діяльності, стимулювання рефлексивного ставлення до процесу формування лідерських якостей, здійснення моніторингу рівня сформованості у студентів лідерських якостей.

Під час проведення експерименту ми разом зі студентами спеціальності «Освітні педагогічні науки» використовували різноманітні технології формування лідерських якостей: тренінги, онлайн-заняття, суди, вебінари, зустрічі, індивідуальну роботу тощо. На основі отриманих даних нами розроблено тести, анкетування, вправи та завдання для формування лідерських якостей майбутнього викладача ЗВО. Вони показують результативність нашої роботи.

Перспективним є вивчення особливостей використання інформаційних технологій для підвищення рівня лідерської компетентності.

\section{СПИСОК ВИКОРИСТАНИХ ДЖЕРЕЛ}

1. Адлер А. Практика и теория индивидуальной психологии. Психологические технологии. Москва : Академический Проект, 2015. 240 с.

2. Дідух Л. Контекстне навчання майбутніх рятувальників в умовах університету. Педагогіка і психологія професійної освіти. 2018. № 2. С. 124-130.

3. Інноваційні педагогічні технології у системі неперервної професійної освіти : монографія. Житомир, 2015. 368 с.

4. Стратегія розвитку сфери інноваційної діяльності на період до 2030 р. від 10 липня 2019 р. № 526-p. URL: https://zakon.rada.gov.ua/laws/show/526-2019-\%D1\%80\#Text( дата звернення 28.03.2021).

5. Шатун В. Компетентності лідерства як детермінанта ефективності сучасного менеджера. Економіка. 2017. B. 294. T. 306. C. 73-79 URL: https://journals.indexcopernicus.com/api/file/viewByFileId/361994.pdf.

6. Штогрин О., Прокопів Л. Основні підходи до розуміння лідерських якостей майбутнього викладача ЗВО. Бюлетень кафедри педагогіки та освітнього менеджменту імені Богдана Ступарика. 2020. № 32. С. 65-70. URL: https://kpibs.pnu.edu.ua/wp-content/uploads/sites.

7. Werzejska J., Karpenko O. Wizja kariery zawodowej młodzieży polskiej i ukraińskiej kończącej studia pedagogiczne. Kraków : Impuls, 2015. 264 s.

\section{REFERENCES}

1. Adler A. Praktyka y teoryia yndyvydualnoi psykholohyy. Psykholohycheskye tekhnolohyy [Practice and theory of individual psychology. Psychological technologies] Moskva: Akademycheskyi Proekt, 2015. 240 p. [in Russian].

2. Didukh L. Kontekstne navchannia maibutnikh riatuvalnykiv v umovakh universytetu. [Contextual presentation of maybuttal ideas in the minds of the university]. Pedagogy and psychology of professional education, 2018. № 2. pp. 124-130 [in Ukrainian].

3. Innovatsiini pedahohichni tekhnolohii u systemi neperervnoi profesiinoi osvity [Innovative pedagogical technologies in the system of continuing professional education: monograph]. Zhytomyr, 2015. 368 p. [in Ukrainian].

4. Stratehiia rozvytku sfery innovatsiinoi diialnosti na period do 2030 roku. [Strategy for the development of innovation in the period up to 2030]. Available at: https://zakon.rada.gov.ua/laws/show/526-2019-\%D1\%80\#Text [in Ukrainian].

5. Shatun V. (2017). Kompetentnosti liderstva yak determinanta efektyvnosti suchasnoho menedzhera. [Leadership competencies are a determinant of the effectiveness of a modern manager]. Ekonomika. T. 1. № 2 (94). pp.73-79. Available at: https:journals.indexcopernicus.com/api/file/viewByFileId/361994.pdf [in Ukrainian].

6. Shtohryn O., Prokopiv L. (2020). Osnovni pidkhody do rozuminnia liderskykh yakostei maibutnoho vykladacha ZVO. [Basic approaches to understanding the leadership qualities of a future freelance teacher] Biuleten kafedry pedahohiky ta osvitnoho menedzhmentu imeni Bohdana Stuparyka. № 32. Pp. 65-70. Available at: https://kpibs.pnu.edu.ua/wp-content/ uploads/sites [in Ukrainian].

7. Werzejska J., Karpenko O. (2015). Wizja kariery zawodowej młodzieży polskiej i ukraińskiej kończącej studia pedagogiczne [A vision of the professional career of Polish and Ukrainian youth graduating from pedagogical studies]. Kraków: Impuls. 264 p. [in Polish]. 